\title{
DANA ASPIRASI DPR RI \\ DALAM PERSPEKTIF PERENCANAAN PEMBANGUNAN NASIONAL
}

\author{
Koko Enang \\ Dosen Tetap Universitas Nurtanio Bandung \\ e-mail: kokoenang@yahoo.com
}

\begin{abstract}
ABSTRAK. Dalam era reformasi dewasa ini kecenderungan orang/masyarakat bebas untuk berbicara, bebas untuk berekspresi, dan bebas mengkritik pemerintah. Berbicara atau mewacanakan sesuatu, ketika yang menyampaikannya seorang pejabat Negara sudah barang tentu akan menjadi perhatian bagi masyarakat. Salah satunya, ketika anggota DPR RI dari Partai Golongan Karya (Golkar) mewacanakan dana aspirasi untuk tiap anggota dewan sebesar Rp 13 milyar ternyata menuai tanggapan negatif dari masyarakat. Barangkali suatu kewajaran, masyarakat bereaksi negatif terhadap wacana yang digulirkan. Dilihat dari sudut pandang ketatanegaraan, DPR sebagai lembaga legislatif merupakan lembaga pembuat undang-undang dan sebagai pelaksana undang-undangnya adalah pemerintah (eksekutif). Artinya, ketika seorang Dewan melaksanakan anggaran tersebut untuk kepentingan pembangunan yang berada di daerah pemilihannya, jelas akan menyalahi dan bertentangan dengan fungsi dan wewenang sebagaimana tersebut di atas. Dana aspirasi dilihat dalam pembangunan nasional, menurut penulis memiliki kaitan dengan pendapat Bintoro Tjokroamidjojo (1978:189-191) mengenai "Unsur-unsur Perencanaan Pembangunan yang Kontinu". Yaitu, 1) sifat rencana itu sendiri sebagai dasar pelaksanaannya sudah mengandung ciri-ciri yang berorientasi pada pelaksanaan; 2) perencanaan tetap mengandung unsur kontinuitas dan fleksibilitas; 3) mengusahakan perencanaan dapat seoprasional mungkin; 4) adanya sistem pengendalian pelaksanaan pembangunan yang mengusahakan keserasian antara pelaksanaan dan perencanaan; dan 5) Bagi proses penyesuaian kembali rencana dan pelaksanaannya serta bagi pengendalian pelaksanaan, diperlukan adanya sistem pelaporan dan evaluasi.
\end{abstract}

Kata Kunci : Dana Aspirasi DPR RI, Perencanaan Pembangunan Nasional

\section{DPR RI ASPIRATION FUND IN NATIONAL DEVELOPMENT PLANNING PERSPECTIVE}

ABSTRACT. In reformation era at recent time people have tendency free to talk, free to expression, and free to criticize government. Talk or discuss something, when it was said by a public officer, it will makes a big attention for people. One of them, when member of center council from Golkar party suggested aspiration fund for each council member 13 billion, it got negative respond from people. It may be a equity, people reacted negatively to the suggestion that was raised. Looked from 
county administration, council as legislative institute is law maker institute and as law executor is government (executive). It's mean a council member uses this budget to development that happened in his vote area, clearly will trespass and interfere with function and authority of member of council. Then this aspiration fund looked by national development perspective based to Bintoro Tjokroadmidjojo opinion (1978:189-191) about "Continue Development Planning Element". There are : 1) planning character itself as base of execution have contained marks whose orientate to the execution; 2) planning fix to contains continuous element and flexibility; 3) attempts planning as operational as possible; 4) there is control system of development execution that attempts to harmony between execution and planning; and 5) for back adaptation process and it's execution and also execution supervisor, needs report system and evaluation.

Keyword : DPR RI aspiration fund, national development fund

\section{PENDAHULUAN}

Wacana mengenai dana aspirasi yang disampaikan Partai Golongan Karya (Golkar) Dewan Perwakilan Rakyat Republik Indonesia (DPR RI), yakni RP 13 $\mathrm{M} /$ anggota. Asumsi dan atau isu yang dibangun munculnya dana aspirasi menurut Anis Matta (Sekretaris Jendral) Partai Keadilan Sejahtera PKS) pada acara dialog yang disiarkan "Metro TV". Salah satu isunya adalah mengenai "proses dan hasil pembangunan yang tidak merata". Dasar argumen atau isu tersebut, jelas dapat terbantahkan, apabila dikaitkan dengan keterwakilan, di mana anggota DPR RI merupakan representasi dari pemilih yang berada pada daerah pemilihan, artinya ketika di suatu daerah atau pulau memiliki jumlah penduduk atau hak pilih yang besar, maka hak keterwakilan di DPR akan lebih banyak, dibandingkan dengan daerah yang memiliki penduduk atau hak pilih yang sedikit berarti pula akan memperoleh kursi atau keterwakilan di DPR yang sedikit. Contoh : Bandingkan jumlah penduduk yang berada di pulau Jawa dengan penduduk yang berada di pulau Irian Jaya, jelas jumlah penduduk dan hak pilih di pulau Jawa akan lebih besar di bandingkan dengan di Irian Jaya, hal ini berarti pula akan membawa dampak terhadap jumlah kursi atau keterwakilah di DPR RI dan akan berpengaruh pula terhadap besaran perolehan dana aspirasi pada tiap daerah. Dengan kondisi seperti itu, yang jadi pertanyaan, apakah pembangunan akan merata, jawaban yang pasti, jelas pembangunan tidak akan merata. Hal tersebut baru dilihat dari satu sisi, apalagi kalau dilihat dari sisi lainnya antara lain, luas wilayah / daerah, kondisi ekonomi, kondisi infra struktur dan supra struktur serta kekayaan alam.

Runtuhnya rezim orde baru (baru) dan bergulirnya era reformasi menunjukkan perubahan yang "dramatis". Ketika masa orde baru (orba), kecenderungan orang/masyarakat memiliki keterbatasan dan kehati-hatian dalam berbicara terutama terkait dengan kritikan yang tajam terhadap negara, maka ganjaran penangkapan, pencekalan dan bahkan hukuman akan selalu menanti bagi mereka yang berani mengkritik. Sementara pada masa sekarang, yang nota bene era reformasi orang/masyarakat atau siapapun, bebas untuk berbicara, 
berwacana, melakukan kritik yang tajam dan pedas, dan bahkan lebih radikal lagi melakukan penghinaan baik melalui perkataan atau pun melalui simbol-simbol terhadap para pemimpin negara termasuk di dalamnya seorang Kepala Negara (presiden), sudah merupakan hal biasa dan sedang berlangsung di Indonesia. Kondisi demikian menunjukkan bahwa, dalam era reformasi sekarang ini orang/masyarakat lebih responsif, atas ketidak adilan dan ketidak berpihakan terhadap masyarakat terutama masyarakat kalangan kelas bawah.

Ketika seorang pejabat negara yang merupakan salah satu anggota DPR dari Golkar mengusulkan dan mewacanakan dana aspirasi menimbulkan kecaman dari berbagai kalangan masyarakat. Secara umum masyarakat berpandangan bahwa, dana aspirasi merupakan model KKN (Kolusi, Korupsi dan Nepotisme) yang dilegalisasi sehingga mereka memiliki keleluasaan dalam melakukan negosiasi dengan para konstituen di daerah pemilihannya masing-masing. Model ini, apabila disetujui akan memberikan peluang KKN. Selain itu, bukan itu saja dana aspirasi dapat memberikan keringanan dan keleluasaan bagi para anggota Dewan dalam melakukan konsolidasi dan komitmen bersama dalam melanggengkan posisinya. Dengan kata lain, mereka tidak perlu lagi mengeluarkan dana/biaya dalam melakukan kampanyenya di masa yang akan datang.

\section{PERENCANAAN PEMBANGUNAN NASIONAL Konsep Perencanaan Pembangunan}

Perencanaan pembangunan merupakan sebuah rancangan atau desain kegiatan-kegiatan, tahapan-tahapan serta prosedur perencanaan pembangunan menuju pada perubahan-perubahan ke arah yang lebih baik dan mengeliminasi akibat/ gangguan-gangguan negatif yang ditimbulkan dari padanya. Dalam abad modern dewasa ini yang ditandai dengan makin pesatnya perkembangan ilmu pengetahuan dan teknologi, perencanaan pembangunan harus mampu memperkirakan/meramalkan (forecast) dan mengantisipasi perkembangan atas ketidakpastian terhadap perubahan masa kini dan masa yang akan datang. "Berbicara mengenai prakiraan dan antisipasi keadaan yang akan datang berarti harus melakukan perencanaan secara cermat, baik menggunakan teknik yang sederhana maupun teknik yang paling canggih". (Sudriamunawar, 2010:62).

Perencanaan pembangunan yang dilaksanakan oleh negara/pemerintah pada hakekatnya dalam upaya mensejahterakan rakyatnya, oleh karenanya pembangunan akan sangat kental dengan masalah pertumbuhan ekonomi. Karena itu, tingkat keberhasilan pembangunan dalam suatu negara salah satu ukuran/indikatornya adalah kemampuan/pertumbuhan ekonomi masyarakat. Pembangunan dilaksanakan tidak hanya bidang ekonomi semata tetapi menyangkut bidang ideologi, politik, sosial, budaya, informasi, sumber daya manusia, keamanan dan pertahanan serta agama.

Berdasarkan asumsi di atas, membuat/menyusun sebuah perencanaan yang baik dalam upaya mencapai suatu tujuan merupakan hal yang sangat mendasar dan penting. Lebih jauh Bintoro Tjokroamidjojo (2010:62) menyebutkan manfaat perencanaan sebagai alat atau cara untuk mencapai tujuan dengan baik yaitu : 
1. Dengan adanya perencanaan diharapkan terdapatnya suatu kegiatan, adanya pedoman bagi pelaksanaan kegiatan-kegiatan yang ditujukan kepada pencapaian tujuan pembangunan;

2. Dengan perencanaan maka dilakukan suatu perkiraan (forcasting) terhadap hal-hal dalam masa pelaksanaan yang akan dilalui. Perkiraan dilakukan mengenai potensi-potensi dan prospek-prospek perkembangan, juga mengenai resiko-resiko yang mungkin di hadapi. Perencanaan mengusahakan supaya ketidak pastian dapat dibataasi sedikit mungkin;

3. Perencanaan memberikan kesempatan untuk memilih berbagai alternative tentang cara terbaik atau memilih kombinasi cara yang terbaik;

4. Dengan perencanaan dilakukan penyusunan skala prioritas, memilih urutanurutan dari segi pentingnya suatu tujuan, sasaran dan kegiatan usahanya;

5. Dengan adanya rencana maka akan ada suatu alat pengukur atau standar untuk mengadakan pengawasan atau evaluasi.

Dalam menyusun dan membuat perencanaan pembangunan diperlukan kematangan, kecermatan dan komprehensif terhadap berbagai kebutuhan suatu Negara/pemerintah dalam mencapai tujuannya. Bintoro Tjokroamidjojo (1986:189) menyebutkan unsur-unsur proses perencanaan yang kontinu sebagai berikut :

1. Sifat rencana itu sendiri sebagai dasar pelaksanannya sudah mengandung ciriciri yang berorientasi kepada pelaksanaan, dalam arti memungkinkan untuk pelaksanaannya;

2. Perencanaan tetap mengandung unsur kontinuitas dan fleksibilitas;

3. Memungkinkan perencanaan dapat seoperasional mungkin;

4. Adanya sistem pengendalian pelaksanaan pembangunan yang mengusahakan keserasian antara pelaksanaan dan perencanaan; dan

5. Bagi proses penyesuaian kembali rencana dan pelaksanaan serta bagi pengendalian pelaksanaan, diperlukan adanya sistem pelaporan dan evaluasi dalam proses perencanaan.

\section{Sistem Perencanaan Pembangunan Nasional}

Dalam Undang-undang Nomor 25 tahun 2004 pasal 1 ayat (3) disebutkan bahwa, sistem perencanaan pembangunan Nasional adalah satu kesatuan tata cara perencanaan pembangunan untuk menghasilkan rencana-rencana pembangunan dalam jangka panjang, jangka menengah, dan tahunan yang dilaksanakan oleh unsur penyelenggara Negara dan masyarakat di tingkat Pusat dan Daerah. Merujuk kepada pasal tersebut, bahwa perencanaan pembangunan terbagi menjadi 3 (tiga) tahapan yaitu,

1. Rencana Pembangunan Jangka Panjang (RPJP), yaitu suatu perencanaan pembangunan untuk periode 20 (dua puluh) tahun;

2. Rencana Pembangunan Jangka Menengah (RPJM), yaitu suatu perencanaan pembangunan untuk periode 5 (lima) tahun; dan

3. Rencana Pembangunan Tahunan Nasional, yaitu Rencana Kerja Pemerintah (RKP) untuk periode 1 (satu) tahun.

Dari ke 3 (tiga) tahapan perencanaan pembangunan, sehingga menghasilkan rencana-rencana pembangunan melibatkan unsur : 
1. unsur penyelenggara Negara mulai tingkat daerah sampai dengan tingkat pusat; dan

2. unsur masyarakat.

Berdasarkan hal di atas, menunjukkan bahwa Perencanaan Pembangunan Nasional bersipat buttom-up planning, artinya penyusunan perencanaan pembangunan berangkat dari bawah yang tentunya bersipat aspiratif. Adapun wujud implementasinya yaitu berupa Musyawarah Perencanaan Pembangunan (Musrenbang). Kegiatan Musyawarah Perencanaan Pembangunan (Musrenbang) yang termaktub dalam Undang undang Nomor 25 tahun 2004 terdapat dalam pasal 11 ayat (1), (2), (3) dan (4) sebagai berikut:

(1) Musrenbang diselenggarakan dalam rangka menyusun RPJP dan diikuti oleh unsur-unsur penyelenggara Negara dengan mengikutsertakan masyarakat;

(2) Menteri menyelenggarakan Musrenbang Jangka Panjang Nasional;

(3) Kepala Bappeda menyelenggarakan Musrenbang Jangka Panjang Daerah;

(4) Musrenbang Jangka Panjang Nasional sebagaimana dimaksud pada ayat (2) dan Musrenbang Jangka Panjang Daerah sebagaimana dimaksud pada ayat (3) dilaksanakan paling lambat 1 (satu) tahun sebelum berakhirnya periode RPJP yang sedang berjalan.

Kegiatan Musyawarah Perencanaan Pembangunan (Musrenbang) tingkat Kabupaten/Kota dilaksanakan dengan tahapan berikut ini:

1. Musrenbang tingkat Desa/Kelurahan;

2. Musrenbang tingkat Kecamatan;

3. Musrenbang tingkat Kabupaten/Kota;

Dilihat dari tataran konsep, perencanaan pembangunan tersebut sangat ideal dan menunjukkan aspiratif sebagai upaya mengakomodir kepentingan dan/atau kebutuhan daerah masing-masing yang tidak bisa digeneralisasi.

\section{Tugas, Fungsi dan Wewenang DPR}

Pembagian kekuasaan/pemisahan kekuasaan di berbagai Negara demokratis pada hakekatnya dapat dibagi menjadi 3 (tiga) bagian, Pertama, kekuasaan legislatif atau membuat undang-undang ( rulemaking function); kedua, kekuasaan eksekutif atau kekuasaan melaksanakan undang-undang ( rule application function); ketiga, kekuasaan yudikatif atau kekuasaan mengadili atas pelanggaran undang-undang ( rule adjudication function (Budiardjo, 1978:151).

Ketiga Pembagian kekuasaan tersebut di atas merupakan konsep trias politica dan yang pertama kali mengemukakannya adalah John locke pada tahun (16321704) dan Montesquieu pada tahun (1689-1755). Konsep dimaksud pada hakekatnya diterapkan dan/atau digunakan di Indonesia dalam konteks sistem ketatanegaraan. Kekuasaan Pemerintahan Negara yang tercantum dalam Bab III merupakan kekuasaan Presiden (eksekutif) sebagai lembaga kekuasaan untuk melaksanakan Undang-undang (rule application function). Kekuasaan/kewenangan Presiden (eksekutif) yang termaktub dalam Undangundang Dasar tahun 1945 yang telah di amandemen sebanyak 17 pasal yang 
terdiri dari : pasal 4, pasal 5, pasal 6, pasal 6A, pasal 7, pasal 7A, pasal 7B, pasal $7 C$, pasal 8 , pasal 10 , pasal 11 , pasal 12 , pasal 13 , pasal 14 , pasal 15 , pasal 16 dan pasal 17. Sementara kekuasaan/kewenangan Dewan Perwakilan Rakyat (DPR) sebagai lembaga legislatif sebagaimana yang termaktub dalam bab VII memiliki kekuasaan/kewenangan sebanyak 7 pasal yaitu terdiri dari : pasal 19, pasal 20, pasal 20A, pasal 21, pasal 22A, dan pasal 22B. Terakhir kekuasaan/kewenangan yudikatif yang termaktub dalam bab IX sebanyak 5 (lima) pasal yaitu mulai pasal 24, pasal 24A, pasal 24B, pasal 24C dan pasal 25.

Sesuai dengan permasalahan dalam makalah ini, kaitannya dengan dana aspirasi yang diwacanakan anggota DPR pusat, perlu penulis kemukakan secara lebih rinci mengenai tugas, fungsi dan wewenang Dewan Perwakilan Rakyat (DPR) yang merupakan lembaga perwakilan rakyat dan sekaligus berkedudukan sebagai lembaga negara. Dalam Undang-undang Nomor 27 tahun 2009 tentang MPR, DPR, DPD dan DPRD.

Dalam pasal 69, Undang-undang Nomor 27 tahun 2009 disebutkan bahwa fungsi DPR terdiri dari :
a) legislasi;
b) anggaran; dan
c) pengawasan.

Fungsi legislasi dalam tataran inplementasi merupakan perwujudan DPR selaku pemegang kekuasaan membentuk undang-undang, fungsi anggaran dalam tataran implementasi merupakan upaya pembahasan dan memberikan persetujuan atau tidak memberikan persetujuan terhadap rancangan undang-undang tentang Anggaran Pendapatan dan Belanja Negara (APBN) yang di ajukan presiden (eksekutif), dan fungsi pengawasan dalam tataran implementasi yaitu suatu upaya melakukan pengawasan atas pelaksanaan undang-undang dan APBN.

Berkaitan dengan tugas dan wewenang DPR termaktub dalam pasal 71, Undang-undang Nomor 27 tahun 2009 disebutkan sebagai berikut :

a) Memberikan persetujuan atau tidak memberikan persetujuan terhadap peraturan pemerintah pengganti undang-undang yang diajukan oleh Presiden untuk menjadi undang-undang;

b) Menerima rancangan undang-undang yang diajukan oleh DPD berkaitan dengan otonomi daerah, hubungan pusat dan daerah, pembentukan dan pemekaran serta penggabungan daerah, pengelolaan sumber daya alam dan sumber daya ekonomi lainnya, serta berkaitan dengan perimbangan keuangan pusat dan daerah;

c) Membahas rancangan undang-undang yang diajukan oleh Presiden atau DPR yang berkaitan dengan otonomi daerah, hubungan pusat dan daerah, pembentukan dan pemekaran serta penggabungan daerah, pengelolaan sumber daya alam dan sumber daya ekonomi lainnya, serta perimbangan keuangan pusat dan daerah dengan mengikutsertakan DPD sebelum diambil persetujuan bersama antara DPR dan Presiden;

d) Memperhatikan pertimbangan DPD atas rancangan undang-undang tentang APBN dn rancangan undang-undang yang berkaitan denan pajak, pendidikan, dan agama; 
e) Membahas bersama presiden dengan memperhatikan pertimbangan DPD dan memberikan persetujuan atas rancangan undang-undang tentang APBN yang diajukan oleh Presiden;

f) Melakukan pengawasan terhadap pelaksanaan undang-undang dan APBN;

g) Membahas dan menindaklanjuti hasil pengawasan yang disampaikan oleh DPD terhadap pelaksanaan undang-undang mengenai otonomi daerah, pembentukan pemekaran dan penggabungan daerah, hubungan pusat dan daerah, pengelolaan sumber daya alam dan sumber daya ekonomi laiannya, pelaksanaan APBN, pajak, pendidikan dan agama;

h) Memilih anggota BPK dengan memperhatikan pertimbangan DPD;

i) Membahas dan menindaklanjuti hasil pemeriksaan atas pengelolaan dan tanggung jawab keuangan Negara yang disampaikan oleh BPK;

j) Memberikan persetujuan kepada presiden atas pengangkatan dan pemberhentian anggota komisi yudisial;

k) Memberikan persetujuan calon hakim agung yang diusulkan Komisi Yudisial untuk ditetapkan sebagai hakim agung oleh Presiden;

I) Memilih 3(tiga) orang hakim konstitusi dan mengajukannya kepada Presiden untuk diresmikan dengan keputusan Presiden;

m) Menyerap, menghimpun, menampung dan menindaklanjuti aspirasi masyarakat; dan

n) Melaksanakan tugas dan wewenang lain yang diatur dalam undang-undang.

Fungsi dan wewenang DPR, ketika dicermati memang secara eksplisit mengenai pengajuan dana aspirasi tidak termaktub dalam fungsi dan wewenang DPR yang ada hanyalah sebagaimana yang tersurat dan tersirat pada poin (S) yaitu "menyerap, menghimpun, menampung, dan menindaklanjuti aspirasi masyarakat". Hal ini akan dijelaskan pada bagian berikutnya.

\section{ANALISIS DANA ASPIRASI DALAM PERSPEKTIF PERENCANAAN PEMBANGUNAN NASIONAL}

Pada bagian ini, pembahasan dan analisa mengenai dana aspirasi dalam perspektif perencanaan pembangunan dapat dilihat dari berbagai sudut pandang (perspektif) dan yang akan di uraikan penulis salah satunya didasarkan pada pendapat Bintoro Tjokroamidjojo ( 1978:190-192), mengenai "unsur-unsur proses perencanaan yang kontinu" yaitu:

\section{Sifat Rencana Itu Sendiri Sebagai Dasar Pelaksanaannya Sudah Mengandung Ciri-Ciri Yang Berorientasi Kepada Pelaksanaan, Dalam Arti Memungkinkan Untuk Pelaksanannya.}

Dalam menyusun sebuah rencana harus sudah dipastikan bahwa rencana tersebut dapat dilaksanakan paling tidak dengan mempertimbangkan waktu dan biaya. Hal ini penting supaya memperoleh jaminan yang lebih besar dalam merealisasikan tujuan dan sasaran-sasaran yang telah direncanakan. Lembaga/Badan/Dinas yang memiliki tugas, fungsi dan wewenang membuat dan menyusun rencana pembangunan untuk tingkat Kabupaten/Kota dan Propinsi, instansi yang menanganinya adalah Badan Perencanaan Pembangunan Daerah 
(Bappeda) sedangkan untuk tingkat nasional adalah Badan Perencanaan Pembangunan Nasional (Bappenas). Karena rencana pembangunan menggunakan sistem perencanaan dari bawah (buttom-up planning system), maka perencanaan yang telah di buat dan disusun Bappeda didasarkan pada hasil musyawarah rencana pembangunan (musrenbang) begitu pun Rencana pembangunan yang telah disusun oleh Bappenas.

Mekanisme perencanaan pembangunan yang dibangun melalui button-up planning secara konsep sudah menunjukkan bahwa, rencana-rencana pembangunan yang telah disusun baik oleh Bappeda maupun Bappenas sudah barang tentu bersifat aspiratif. Namun ketika anggota Dewan mewacanakan dana aspirasi bagi setiap anggota Dewan sebesar Rp. 13 Milyar dengan alasan hasil pembangunan tidak dirasakan oleh masyarakat, tidak heran menimbulkan pertanyaan besar. Dan yang jadi pertanyaannya adalah, ketika penyusunan rencana pembangunan yang diajukan eksekutif kepada DPR mulai dari proses pembahasan sampai pada persetujuan, sejauhmana peran dan keberpihakannya terhadap masyarakat dalam tataran kebijakan. Artinya ketika eksekutif mengajukan rancangan pembangunan ternyata benar-benar tidak menggambarkan keberpihakan kepada rakyat/masyarakat, kenapa tidak menggunakan fungsi dan wewenangnya yaitu menolak. Oleh karenanya seorang pemimpin atau seorang anggota dewan yang merupakan representasi suara masyarakat/rakyat dituntut memiliki komitmen dan kepekaan yang kuat dalam memperjuangkan masyarakat/rakyatnya bukan hanya sekedar "gemar berwacana" dalam upaya meraih simpati, lebih penting dari itu semua adalah tataran implementasi yang nyata (rill).

\section{Proses Perencanaan Tetap Mengandung Unsur Kontinuitas Dan Fleksibilitas.}

Dalam hal kontinuitas dan fleksibilitas, sebuah perencanaan dikembangkan dengan istilah rolling plan yaitu suatu perencanaan dimana pada setiap akhir tahun (periode tertentu) pelaksanaan rencana disesuaikan kembali dengan sasaran-sasaran, program-program dan proyek-proyek rencana untuk tahun (periode terentu) berikutnya. Ketika sasaran-sasaran, program-program dan proyek-proyek yang telah direncanakan oleh eksekutif, tepat dan tidaknya sasaran dan apakah sesuai dengan kebutuhan masyarakat/rakyat, seorang anggota dewan akan mampu mengoreksi apabila mengetahui persis minimal tentang kondisi dan potensi daerah pemilihannya masing-masing. Dengan kata lain seorang anggota dewan mengetahui mengenai kondisi dan potensi daerahnya, bukan hanya didasarkan kepada laporan dan informasi semata, lebih dari itu, tahu secara langsung mengenai kebutuhan-kebutuhan dan potensi-potensi yang harus dikembangkan di daerah pemilihannya masing-masing. Kesemuanya itu sudah barang tentu dalam tataran implementasinya disesuaikan dengan fungsi dan wewenang yang dimilikinya sehingga diharapkan manfaatnya dapat dirasakan langsung oleh masyarakat.

Paradigma yang harus terus dibangun dan dikembangkan oleh seorang anggota Dewan yaitu bagaimana minimal membangun hubungan komunikasi 
dalam upaya pencerahan terhadap daerah pemilihnnya. Kontinuitas dan fleksibilitas bukan hanya berlaku dalam konteks proses perencanaan semata tetapi lebih dari itu, dapat digunakan dalam konteks hubungan komunikasi dengan para pendukung atau masyarakat. Masyarakat memerlukan pembinaan, pengarahan, sosilisasi, sehingga pola pemikirannya akan lebih berkembang dan kritis, baik mengenai pendidikan politik, kebijakan pembangunan atau kebijakan-kebijakan politik yang telah digulirkan serta mengoreksi, menerima dan mengkaji aspirasi dan potensi yang ada di masyarakat sehingga dapat dijadikan sebagai bahan referensi dan perjuangan dalam membuat regulasi.

\section{Mengusahakan Perencanaan Dapat Seoperasional Mungkin.}

Maksudnya bahwa, perencanaan ini erat kaitannya antara perencanaan tahunan dengan anggaran belanja tahunan dalam suatu Negara. Secara umum bagi Negara dunia ketiga (Negara berkembang) termasuk Indonesia memiliki keterbatasan dengan masalah anggaran. Perencanaan akan menjadi operasional ketika didukung oleh adanya ketersediaan anggaran, artinya perencanaan pembangunan tahunan akan dapat direalisasikan dan atau dilaksanakan apabila Anggaran Pendapatan dan Belanja Negara (APBN) mampu membiayai atau menyediakan besaran anggaran yang dibutuhkan. Dalam menutupi kebutuhan anggaran dimaksud, pada dasarnya terdapat 3 (tiga) pos anggaran yaitu ketersediaan atas dasar kemampuan keuangan negara, bantuan atau hibah dari Negara lain, dan dana pinjaman.

Dalam mengajukan rancangan undang-undang tentang APBN yang dilakukan pemerintah (eksekutif) kepada DPR (legislatif). Sebagai langkah awal sebelum memberikan persetujuan sudah barang tentu DPR terlebih dahulu melakukan pembahasan. Ada 2 (dua) fungsi DPR yang melekat dalam kegiatan ini yaitu 1) perwujudan DPR selaku pemegang kekuasaan membentuk undang-undang (melaksanakan fungsi legislasi); dan 2) membahas dan memberikan persetujuan atau tidak memberikan persetujuan terhadap rancangan undang-undang tentang APBN yang diajukan oleh Presiden (melaksanakan fungsi anggaran).

Pada posisi inilah, barang kali anggota Dewan memiliki peran yang sangat strategis, baik menyangkut pembahasan perencanaan pembangunan tahunan dan kemudian ditindaklanjuti dengan pos-pos anggaran kegiatan. Yang jadi pertanyaan besar, apakah pada waktu pembahasan perencanaan pembangunan tahunan, anggota Dewan sudah mengkaji benar item-item kegiatan pembangunan yang kesemuanya itu mencerminkan kebutuhan dan meningkatkan perekonomian serta pembangunan masyarakat kelas bawah, dan pertanyaan selanjutnya apakah alokasi anggaran untuk mendukung kegiatan tersebut realistis. Minimal kalau kedua hal tersebut sudah dilakukan, tidak ada lagi alasan bagi anggota Dewan untuk mewacanakan masalah dana aspirasi. Atau sebaliknya, ketika perencanaan pembangunan dan alokasi anggaran kegiatan yang diajukan pemerintah (eksekutif) tidak memihak kepada kepentingan ekonomi dan pembangunan masyarakat kelas bawah, maka sesuai dengan fungsi dan wewenang Dewan dapat menggunakannya yaitu mengenai penolakan atas pengajuan rancangan undangundang APBN. Dengan demikian terkait dana aspirasi, logika sederhananya adalah 
anggota Dewan bukan pelaksana kebijakan tetapi sebaliknya anggota Dewan pembuat kebijakan sebagaimana tersirat dalam Undang-undang Nomor 27 tahun 2009 pasal (69).

\section{Adanya Sistem Pengendalian Pelaksanaan Pembangunan Yang Mengusahakan Keserasian Antara Pelaksanaan Dan Perencanaan.}

Pada bagian ini merupakan tindak lanjut dari tahapan sebelumnya, artinya ketika perencanaan pembangunan dan alokasi anggarannya telah disetujui anggota dewan, maka selanjutnya pemerintah (eksekutif) melaksanakan kegiatankegiatan sebagaimana yang telah dibuat/digariskan dalam perencanaan pembangunan tahunan. Dalam tataran pelaksanaan kegiatan dalam suatu organisasi baik kecil maupun besar, kemungkinan ketidak sesuaian antara perencanaan dengan pelaksanaan bisa terjadi, apalagi Negara merupakan organisasi besar yang memiliki kompleksitas yang tinggi. Kompleksitas dimaksud antara lain, masalah kepentingan, karakterristik, budaya, strata ekonomi, keadaan dan jumlah penduduk, ideologi, politik, adat istiadat, geografis, dan lain-lain.

Ketika perencanaan pembangunan yang telah ditetapkan tidak bisa dilaksanakan karena disebabkan bencana alam (plus mayor), barang kali kejadian tersebut dapat ditolelir karena masalah bencana alam, siapapun tidak akan bisa memprediksi dengan tepat mengenai waktu kejadiannya meskipun memiliki kecanggihan dan kemajuan teknologi. Namun ketika perencanaan tidak sesuai dengan pelaksanaan yang disebabkan oleh pelaku atau pelaksana secara disengaja untuk menyelewengkan demi kepentingan/keuntungan individu maupun kelompok dan merugikan masyarakat/Negara, hal ini tentunya tidak dapat ditolelir dan perlu mendapat sanksi hukum bagi siapapun yang melakukan ataupun terlibat di dalamnya.

Dalam tataran sistem ketatanegaraan Indonesia, lembaga/Badan/Instansi yang memiliki wewenang untuk melakukan pengawasan dan pengendalian pelaksanaan kegiatan dengan menggunakan keuangan Negara yaitu Badan Pemeriksa Keuangan (BPK), Inspektorat Jenderal (Irjen), Badan Pemeriksa Keuangan dan Pembangunan (BPKP) dan Badan Pengawas Daerah (Bawasda). Sementara anggota Dewan sebagaimana yang tercantum dalam Undang-undang nomor 27 tahun 2009 pasal 69 ayat c dan pasal 70 ayat (3) fungsi dan wewenang DPR dalam bidang pengawasan yaitu melakukan pengawasan terhadap pelaksanaan Undang-undang dan APBN. Dengan kata lain pengawasan yang dilakukan oleh DPR berkenaan dengan segala hal yang menyangkut dengan pelaksanaan Peraturan-peraturan dan perundang-undangan yang telah dibuat, disetujui dan atau disyahkan DPR dan sebagai pelaksananya adalah pemerintah (eksekutif).

Berdasarkan uraian di atas, dikaitkan dengan wacana pengajuan dana aspirasi bagi anggota DPR, seandainya usulan dimaksud disetujui oleh anggota DPR dan kemudian ditetapkan dengan undang-undang yang menjadi pertanyaannya adalah: 1. Apakah anggota DPR dapat melaksanakan secara langsung untuk mengalokasikan dana aspirasi sebesar Rp. 13 milyar pada daerah pemilihannya 
masing-masing karena DPR bukan pelaksana Undang-undang dan yang bisa melaksanakannya adalah Presiden (eksekutif).

2. Apakah tidak akan terjadi ketimpangan dan kecemburuan yang lebih tajam bagi daerah yang nota bene jumlah hak pilihnya kecil sementara kebutuhan mereka lebih besar di bandingkan daerah lain baik menyangkut luas wilayah, struktur ekonomi, ataupun sember/potensi kekayaan alam. Artinya daerah yang memiliki jumlah hak pilih yang besar, akan menerima alokasi dana aspirasi yang besar tetapi sebaliknya jumlah hak pilih yang sedikit akan mendapat alokasi anggaran yang kecil.

3. Apakah tidak akan terjadi dominasi komplik kepentingan dikaitkan dengan pelaksanaan musrenbang sebab dalam pengajuan rencana pembangunan tidak berbicara mayoritas dan atau minoritas pendukung parai politik.

4. Bagi proses penyesuaian kembali rencana dan pelaksanaannya serta bagi pengendalian pelaksanaan, diperlukan adanya sitem pelaporan dan evaluasi

Maksud pada bagian ini merupakan tindak lanjut dari hasil pekerjaan/kegiatan pembangunan yang telah dilaksanakan dalam jangka waktu tertentu (periode tahunan) yang akan dijadikan sebagai bahan kajian dan pertimbangan serta evaluasi dalam menentukan perencanaan dan kebijakan-kebijakan periode kegiatan berikutnya atau sebagai umpan balik ( feed back).

Berbicara umpan balik (feed back) tidak bisa dilepaskan dengan hasil yang telah dicapai (out put), ketika hasil yang telah dicapai belum sesuai dengan target dan atau keinginan yang diharapkan, sudah barang tentu menjadi bahan evaluasi dalam penyusunan perencanaan dan kebijakan-kebijakan selanjutnya. Hal ini menunjukkan bahwa, perencanaan pembangunan yang telah dilaksanakan pemerintah (eksekutif) dalam jangka waktu pembangunan satu tahun angaran, sudah pasti, akan selalu di evaluasi untuk menentukan dan menyusun programprogram dan kebijakan-kebijakan perencanaan pembangunan untuk tahun berikutnya. Kegiatan tersebut dalam tataran implementasi, perencanaan pembangunan dan yang menjadi leading sectornya Bappeda untuk tingkat Kabupaten/Kota dan tingkat Propinsi serta untuk tingkat Nasional adalah Bappenas. Artinya perencanaan pembangunan yang telah dibahas pada tahun 2010 melalui mekanisme yang telah ditetapkan, maka perencanaan tersebut dapat direalisasikan atau di implementasikan pada tahun 2011. Mekanisme tersebut terus dibangun sebagai wujud dari proses perencanaan pembangunan yang berkesinambungan, kekurangan-kekurangan dan atau kegagalan-kegagalan pada tahun ini menjadi bahan kajian dan perbaikan tahun berikutnya.

Perencanaan pembangunan dan perencanaan anggaran tahunan yang disusun dan di buat pemerintah (skesutif) tidak bisa mengelak dari persertujuan DPR. Maksudnya, Perencanaan pembangunan dan perencanaan anggaran yang di tuangkan dalam RAPBN tanpa disetujui oleh DPR, maka kegiatan dan atau rencana tersebut tidak bisa dilaksanakan oleh pemerintah (Eksekutif).

Didasarkan pada mekanisme dan fungsi serta wewenang masing-masing lembaga sebagaimana telah disampaikan di atas, rasanya baik logika apalagi peraturan perundang-undangan akan sulit menerima dana aspirasi bagi setiap anggota Dewan. Oleh karenanya pada tahapan ini wacana yang di gulirkan 
anggota Dewan khususnya dari fraksi Golkar perlu dievaluasi lebih mendalam karena tidak menutup kemungkinan ketika disetujui, imbasnya akan merusak terhadap tatanan dan sitem ketatanegaraan sebagaimana telah disampaikan pada bagian sebelumnya, dan lebih parahnya lagi apabila hanya didasarkan kepada kepentingan politik segelintir orang/kelompok orang, bukannya untuk kepentingan dan kemaslahatan masyarakat, bangsa dan Negara.

\section{KESIMPULAN}

1. Dana aspirasi yang diwacanakan partai golkar menuai pro dan kontra. Alasannya yang pro karena dana aspirasi memberikan keringanan dan keleluasaan bagi para anggota DPR untuk melakukan konsolidasi dan komitmen bersama dalam melanggengkan kekuasaan tanpa mengeluarkan biaya, yang kontra bahwa dana aspirasi menumbuhkan model KKN (Korupsi, Kolusi dan Nepotisme). Dan apabila anggota Dewan melaksanakan dan merealisasikan sendiri anggaran tersebut, sangat bertentangan dengan fungsi dan wewenang dan lebih jauh lagi akan merusak terhadap sistem ketatanegaraan.

2. Sistem perencanaan pembangunan nasional bersifat butom-up planning, artinya perencanaan yang didasarkan pada usulan dan kepentingan daerah masing-masing, hal ini menunjukkan pula bahwa perencanaan tersebut bersifat aspiratif, sehingga penggunaan dana aspirasi sesuai dengan kepentingan masyarakat yang sudah terwakili di DPR untuk diperjuangkan menjadi kenyataan dalam membangun daerahnya.

\section{SARAN}

Berdasarkan hasil kajian unsur-unsur perencanaan, yang harus dikembangkan oleh DPR yaitu :

1. Harus ada kejelasan tugas pokok dan fungsi DPR dalam memperjuangkan aspirasi masyarakat dalam perencanaan pembangunan nasional, sehingga aspirasi masyarakat yang diperjuangkan DPR sejalan dengan pemerintah, sehingga keinginan masyarakat bisa dipenuhi dalam meningkatkan kesejateraan masyarakat.

2. Dana aspirasi yang diperjuangkan DPR harus tepat sasaran, jangan sampai digunakan segelintir kepentingan elit politik yang mengatas namakan masyarakat, tetapi kenyataannya tidak tepat sasaran.

\section{DAFTAR PUSTAKA}

Budiardjo, Miriam. 1978. Dasar-dasar Ilmu Politik, Edisi ke 3, Cetakan ke 3, Jakarta : Universitas Indonesia.

Fakih, Mansour. 2008. Runtuhnya Teori Pembangunan dan Globalisasi, Edisi Revisi, Cetakan V, Yogjakarta :Insist Press.

Papasi, J.M. 1994. Ilmu Administrasi Pembangunan Inovasi dan Pembangunan Proyek, Bandung : Pionir Grup. 
Tjokroamidjojo, Bintoro. 1986. Pengantar Administrasi Pembangunan. Jakarta: PT. Dharma aksara Perkasa.

Sudriamunawar, Haryono. 2010. Pengantar Studi Administrasi Pembangunan. Bandung : Koperasi Karyawan Kopertis Wilayah IV.

\section{Peraturan Perundang-undangan}

Undang-undang Nomor 25 Tahun 2004 tentang Sistem Perencanaan Pembangunan Nasional.

Undang-undang Nomor 27 Tahun 2009 tentang MPR, DPR, DPD dan DPRD. 